\title{
Positive inertia and proactive influencing towards sustainability: systems analysis of a frontrunner city
}

\author{
Sigourney Irvine(D) and Xuemei Bai
}

\author{
* Correspondence: Xuemei.Bai@anu. \\ edu.au \\ Fenner School of Environment and \\ Society, Australian National \\ University, Canberra 2601, Australia
}

\begin{abstract}
With an increasingly urban population, cities have an important role to play in global environmental sustainability. Cities engaged in pioneering and ongoing sustainability experimentation - the frontrunners - can lead the way towards sustainability transition, and often become the beacon for others to follow. However, the nature and the internal dynamics that make a city a frontrunner, or the role of frontrunner cities in sustainability transition beyond their boundary, remain unclear. In addition, most studies on the influence of these frontrunners are limited to passive influencing, i.e. how the practice has been duplicated by others, or how the practice is adopted and mainstreamed into system level. Based on in-depth case studies on a frontrunner city and two other cities influenced by it, this paper examines how momentum for positive changes has been initiated, built, and sustained towards changing the status quo of practice through a succession of actors and a series of reinforcing feedback loops. We argue that creating a positive inertia through sustained momentum and embedding the frontrunner identity in a city is essential for it to continue the process of sustainability transition. Frontrunners can create flow-on benefits for other cities through a proactive influencing. Supported by multiple two-way benefits, such proactive influencing is a new mechanism of mainstreaming and up-scaling urban sustainability experiments in system innovation and transition.
\end{abstract}

Keywords: Sustainability transition, System innovation, Urban sustainability experiments, Frontrunners

\section{Science highlights}

- A frontrunner city can produce environmental and economic benefits and opportunities, both within and beyond its boundary through urban experimentation that contributes to sustainability transition.

- Positive changes toward sustainability are created and sustained by a succession of self-reinforcing feedback loops involving citizens, businesses, local and national government.

- Positive inertia is coined to describe an emergent property of a city as a system, where positive approaches are embedded into the city's identity, and thus not influenced by short-term political cycles.

(c) The Author(s). 2019 Open Access This article is distributed under the terms of the Creative Commons Attribution 4.0 International License (http://creativecommons.org/licenses/by/4.0/), which permits unrestricted use, distribution, and reproduction in any medium, provided you give appropriate credit to the original author(s) and the source, provide a link to the Creative Commons license, and indicate if changes were made. The Creative Commons Public Domain Dedication waiver (http://creativecommons.org/ publicdomain/zero/1.0/) applies to the data made available in this article, unless otherwise stated. 
- Building vertical and horizontal linkages is crucial for the success and upscaling of the sustainability experiments conducted by the frontrunner city.

- Proactive influencing is identified as a new phenomenon where frontrunner cities actively influence other cities, which can be a new mainstreaming and upscaling mechanism in system innovation and transition.

\section{Policy and practice recommendations}

- Build momentum from bottom-up initiatives, and try to sustain them through policy and institutional support.

- Enhance citizens' awareness and education and build a narrative around the importance of initiating and continuing sustainability initiatives, to help create and embed an associated new self-identity of pro-sustainability.

- Take an active role towards sustainability-focused, long-term and multi-layered inter-city collaborations.

\section{Introduction}

Cities lie at the heart of dealing with global sustainability challenges. More than twothirds of the world's population is expected to be urbanised by 2050 (United Nations, Department of Econmic and Sovial Affairs, Population Division 2018), with up to $90 \%$ of the world population increase to be added into cities and urban areas in the global south (United Nations, Department of Econmic and Sovial Affairs, Population Division 2018; Nagendra et al. 2018). Cities will play an increasingly important role in the transition towards sustainability, which requires a fundamental societal, economic, political and technological transformation towards more sustainable modes of production and consumption that are long-term and multi-dimensional (Markard et al. 2012; Lange et al. 2013).

Many cities are exploring innovative solutions towards more sustainable development pathways, making them hotbeds for urban sustainability experiments (Bai et al. 2010; Bai et al. 2018). Berkhout et al. (2010) define sustainability experimentation as initiatives that embody innovative technology or practice that is likely to lead to substantial sustainability gains. Bai et al. (2010) emphasize the importance of looking at frontrunner cities in sustainability, both individually and across cases, and find that urban sustainability experiments can be multiplied by others, or up-scaled to change the system of practice, thus playing a significant role in achieving overall sustainability. Nonetheless, achieving broader change is complex, and it is important to understand the specific social context in which the experiment is embedded (Evans et al. 2016). Continuous processes of experimentation and learning that engage diverse actors are crucial to steer transition (Loorbach and Rotmans 2006; Nevens et al. 2013; Frantzeskaki et al. 2014). This is because uncertainty surrounds both the problems and solutions (Broto and Bulkeley 2013), and cities face different challenges at different development stages (Bai and Imura 2000).

Many lessons can be learned from looking at frontrunner cities and their role in sustainability transition. Historically, the bulk of transition research has ignored the role of cities and urban experimentation (cf. Rotmans et al. 2001; Jacobsson and Lauber 2006; Geels and Schot 2007) and instead focused on national level transition management. 
This has been criticised, with recent research highlighting the importance of examining diverse scales and interconnections, socio-spatial context and transcending 'containerized' views of socio-technical systems (Coenen et al. 2012; Truffer et al. 2015).

In addition, a large portion of the existing research has been focussed on European cities (cf. Voytenko et al. 2016; McCormick and Kiss 2015; Frantzeskaki et al. 2018). This is problematic as rapid urbanisation is taking place in Asia and polycentric urban environmental governance, which has been presented as the key to transition, has been studied only in a few cities, with little exploration of this approach in the Asian region (van der Heijden 2018). More recently, some studies focusing on Asia have highlighted conservative development pathways, with challenges in systems thinking and sustainability foresight, and demonstrated an important role for urban sustainability experimentation (Bai et al. 2010; Peng and Bai 2018; Peng et al. 2019; Wolfram 2019). While these studies have advanced our understanding on the importance of experimentations at city level, they emphasise the need for better insight into transition in the Asian region and the system level dynamics and mechanisms underlying the many urban sustainability experiments and their linkages across cities.

The rising number of transnational local government networks for sustainability, such as ICLEI and C40, also shows that cities are increasingly looking for answers from each other (Acuto 2016). However, not all city networks are currently active or effective, with research indicating they need to go further than just information sharing to be successful (Lee and Jung 2018). This highlights the importance of studying linkages between cities as well as within them, and looking at relationships outside of the established global city networks. In terms of researching such linkages, most of the existing studies looking at the influence of frontrunner cities on others have focused on passive influencing, i.e. how others can learn from the innovative practices, and how the practice has been adopted and mainstreamed by others (see for example, Bai et al. 2010; Peng et al. 2019; Gerlak et al. 2018). The internal dynamics and mechanisms through which a frontrunner city can proactively influence others remain unclear. Furthermore, cross-city learning is complex and innovative practices are often not being transferred to the majority of cities (Campbell 2009) - with challenges including a lack of openness and unclear social learning processes (Wolfram et al. 2018). In a recent study exploring the scaling process of urban sustainability experiments, Peng et al. (2019) found that contextualization often requires distinctive configurations to be formed, which is an innovation in itself. To fully understand the role of frontrunner cities in cross-city learning, it is important to examine the cross-city linkages through both the frontrunner city perspective as well as through the perspectives of partner cities.

This study aims to produce an in-depth understanding of the internal mechanisms that contribute to the making of a frontrunner city, and its role in sustainability transition. We aim to answer the following questions: Which elements trigger, enable, hinder and support ongoing sustainability experimentation in cities? How do these factors interact to create a frontrunner city system dynamic? Do frontrunner cities influence/ enable sustainability transitions elsewhere? If so, how?

We explore the case of Kitakyushu City in Japan, because the city has transformed from one of the most polluting cities to a globally recognized frontrunner city with multiple international awards. Not only engaging with ongoing innovative practices, the city has also been active in international cooperation with other Asian cities in 
environment and sustainability areas, extending its sustainability experimentation to the wider Asian region. Understanding the making of Kitakyushu as a frontrunner, as well as systems of cooperation with cities in Indonesia and Vietnam, may prove highly instructive for understanding how local actors can play pivotal roles in building and maintaining momentum towards sustainability.

\section{Conceptual and theoretical perspectives on urban sustainability experimentation and transition}

We introduce several key conceptual and theoretical perspectives, which employ systems thinking, that informed the analytical framework of this research. Socio-technical transition and systems innovation, frames the importance of focusing on experiments that have influenced broader systemic change rather than just individual products. Transitioning towards sustainability requires ongoing experimentation over time, so a temporal and evolutionary perspective underpins how frontrunner cities, hotbeds for urban sustainability experimentation, emerge, maintain their status and have spillover effects. Distilled from this, a systems and evolutionary perspective is adopted to analyse the key elements in urban sustainability experiments, including actors, linkages, triggers and barriers.

\section{Urban sustainability experiments and transition}

Strategic niche management research has long demonstrated that sustainable innovation journeys are facilitated through experimentation in protected spaces that allow co-evolution of user practice, technology and regulatory structures (Ruggiero et al. 2018; Schot and Geels 2008). This is required to prevent early rejection (Raven 2007). The multi-level perspective also highlights the importance of this in conjunction with multi-level socio-technical change for transitioning from one system to another (Geels 2004; Geels 2011). Socio-technical system transitions involve dynamic interactions between systems, actors and institutions (Geels 2004). Systems innovation research, specifically socio-technical transitions, has broadened the scope of analysis, covering not only innovation in technologies but also in policy, culture, user practice, firm management, institutions and regulations (see Berkhout 2002; Kemp and Rotmans 2005; Geels 2006; Schot and Steinmueller 2018). Although the focus in system innovation literature has been on technological or sectoral innovation (cf. Malerba 2002; Bergek et al. 2008), this study is informed by a socio-technical system (STS) approach to the study of urban areas. This STS transition lens helps shine light on the importance of linkages, specifically for dynamics and feedbacks of technologies and society, discussed further below. This is appropriate as it recognizes that cities are complex adaptive systems that are dynamic and open, and constantly evolving (Batty 2008: 770; Bai et al. 2016), the trajectory of which is "shaped by a unique combination of endogenous and exogenous forces" (Bai 2003: 528).

In terms of understanding system level mechanisms, Homer-Dixon et al. (2015) have discussed the development of a causal architecture of failure, where systems can interact to cause a far larger inter-systemic crisis, and then propagate across multiple system boundaries. However, there is a need to further examine the opposite occurring. 
Urban sustainability experiments can lead to broader, substantial sustainability gains and the transition, or systems innovation described above (Berkhout et al. 2010). For example, Curitiba, recipient of the Global Sustainable City Award, is an environmental management frontrunner and twinned with 13 different cities in Asia, Europe and Latin America. The city experimented with ways to improve transport in a low cost way, by dedicating lanes to buses and then establishing faster boarding through use of multiple doors and off-board payment: it established the first Bus Rapid Transit (BRT) system that works like a light rail system but has much lower costs, transforming its transport service. Within the current literature, however, there is still insufficient understanding of urban sustainability experimentation and its trans-local flows (Affolderbach and Schulz 2016). Seyfang and Smith (2007) argue that innovation and community action are key strands for STS transitions, though community action is rarely linked and governments capitalising on grassroots innovation to populate mainstream systems is a challenge. Quitzau et al. (2013) have also noted that the endogenous agency that urban governments have increasingly shown by engaging in planned efforts to adjust the regimes they operate within is not well addressed in transition studies. Although there are studies which have explored sustainable urban transformation, there is a lack of studies looking at the nature and emergence of how a city becomes established as a "frontrunner".

\section{The role of actors and linkages}

Cities can be considered as a human complex system, where multiple actors, constituents, and structures coexist and various processes and linkages occur (Bai et al. 2016). Although transitions cannot be fully planned due to their complexity, they can be steered by actors who may take up a key role (Kemp and Loorbach 2003). This indicates the importance of examining actors, networks and processes. Bai et al. (2010) proposed a five-tier analytical framework of triggers, barriers, actors, linkages and pathways in examining urban sustainability experiments, which can help highlight bottlenecks as well as factors of success. Successful experiments that support transition require a variety of interlinked actors to realign themselves and coordinate financial and institutional resources (Peng et al. 2019). Social networks crossing various levels and organisations are crucial to utilizing knowledge to adapt to events (Peng and Bai 2018; Laakso et al. 2017). Smith et al. (2005) have also argued that sustainable systems innovation approaches have been overly functionalist, meaning a greater analysis of agency is needed to inform more effective processes of transformation. They propose a heuristic framework for understanding transition context and governance, which plots the locus of adaptive resources against the coordination in response to selection pressures. Importantly, they also highlight the relevance of learning at different agency levels including actors, networks and institutions. Agency is a key theme that will be addressed, and is also important for urban change.

Experiments are often part of global knowledge and technology flows. This means that, whether directly or indirectly, experiments in one place will draw on the experience of experiments in another (Berkhout et al. 2010). For example, 171 cities have followed Curitiba to adopt similar BRT systems (BRT+ Centre of Excellence and EMBARQ 2019). As will be discussed later, global technology and knowledge flows are 
important for spillovers of experimentation. De Boer has recognised that an "unprecedented level of cooperation, not only between countries, but also between different levels of governments and the private sector" (de Boer 2009: 1) is needed to tackle global sustainability challenges, such as climate change. Broto and Bulkeley have also pointed to the need for research on the internationalisation of urban environmental governance through intercity linkages (Broto and Bulkeley 2013).

\section{Evolutionary perspective}

Although there is a shared recognition that system innovation is complex and involves different elements and experimentation, it is unclear how different elements interact within a city to drive its behaviour towards sustainability, i.e. how is the momentum built and maintained to drive a city, a frontrunner, towards sustainability is important. Specifically: why do some cities become frontrunners and sustain their status over a long period of time? This temporal perspective is crucial, as one of the key challenges in urban sustainability lies in the short political cycle and resultant lack of continuity of sustainability policies.

An evolutionary perspective provides an important theoretical lens for understanding this temporal perspective. The concept of "urban environmental evolution" recognizes commonalities in longitudinal dynamics across different cities, while emphasizing a non-linearity in their trajectories, and that trajectories are shaped by unique combinations of and interaction among internal and external factors (Bai 2003). System innovation theory also promotes an evolutionary approach (Geels 2005; Schot and Geels 2008), which understands the development of technologies, business strategies, institutions and social practices as being a co-evolutionary process (Ma et al. 2018; Geels 2005). Such evolutionary perspectives are important for understanding how a system changes over time; and for understanding what role agencies, and the dynamic linkages surrounding them, have in influencing such change.

\section{Methodology}

\section{Analytical framework}

As stated above, we draw on various elements of system innovation and transition perspective to help understand how important elements related to Kitakyushu's approach to urban sustainability have interacted and driven transition processes. We focus on experimentation and, drawing on Bai et al. (2010), examine elements proposed in Bai et al. (2009) including triggers, actors, linkages (both vertical and horizontal), and barriers, to illuminate Kitakyushu's emergence as a frontrunner and the nature of the system that maintains its status as a frontrunner. A temporal dynamics and evolutionary perspective is adopted to also understand how these factors and their relationships change over time. The spillover effects of Kitakyushu's transition processes on other cities are explored, also viewed through a systems lens (Meadows 2008) to understand inter-systemic effects between Kitakyushu and the other cities.

\section{Data collection and analysis}

Primary data was collected through semi-structured interviews based on questionnaires developed from the conceptual framework and tailored for different actors. A total of 
35 individuals, 30 from Japan and 5 from Surabaya (Indonesia) and Haiphong (Vietnam), were interviewed during a 3-week field trip to Japan in Tokyo and Kitakyushu in 2015. The initial pool included respondents from Kitakyushu local government, companies and a research institute, and national government. From this, a snowball sampling strategy, a form of purposive sampling, where respondents utilise their social networks to recommend the researcher to other people able to contribute to the study (Mack et al. 2005), is used to identify additional interviewees. To avoid limitation in sample variation, different entrances into the government and industry involved in Kitakyushu city's sustainability activities were chosen. The participants from the other Asian cities were involved in training programs in Kitakyushu, while community participants were identified through local contacts the researcher had in the area. Information collection, storage and presentation are approved by the ANU Human Research Ethics Committee (protocol number: 2015/173). Informed consent was given, and identified participants agreed to be identifiable. Interview data was collected and categorized, and the repetition of certain concepts indicated that the data had reached a level of saturation. Table 1 shows the role and affiliation of respondents.

The analytical framework was mobilised by developing causal loop diagrams to capture the complex interplay between different factors (triggers, actors, linkages) both within and beyond the system, which contributed to analysis of the co-evolution of different elements of the system, relevant to Kitakyushu's approach to sustainability. This was based on the analysis of the data collected through interviews that also applied the framework through the process of coding using QSR NVivo 10 software. These interviews were complemented by literature/document search and analysis, as well as informal conversations with community members and other stakeholders.

\section{The making of a frontrunner city - understanding key system components and dynamics \\ Background of Kitakyushu}

Kitakyushu transformed from the city with the worst air pollution in Japan in the 1960s to an environmental leader. The city has supported and integrated environmental industries, such as recycling, into its existing industrial fabric; developed more sustainable urban infrastructure, and driven urban regeneration through the Eco-Town project; dedicated areas of the city to education and experimentation, such as the Higashida 'green village' area, community-based energy management systems; and developed long-term environmentally focussed urban plans. It dealt with the source of immediate health effects by regulating industry behaviour through introducing emission limits and then later developed urban plans and policies for the city that focused on sustainability: engendering significant urban system change in terms of the city's approach to the economy and environment. Its significant improvement over 20 years in urban sustainability and environmental strategies was recognised by the United Nations Environment Programme's Global 500 award in 1990. Since the establishment of the Yawata Steelworks (later Nippon Steel) in 1901, Kitakyushu has been an industrial centre of steel, iron and chemicals. When the Japanese government's goal to double the nation's income rapidly progressed from 1960, industrialisation intensified, leading to a significant increase in pollution. An absence of laws and political will to regulate environmental 
Table 1 Respondent information

\begin{tabular}{|c|c|c|}
\hline Respondents & Role & Organisation/affiliation \\
\hline GOV1 & $\begin{array}{l}\text { International Cooperation Office, International } \\
\text { Strategy Division }\end{array}$ & Ministry of the Environment, Japan \\
\hline JICA1 & Training Program Division & Japan International Cooperation Agency \\
\hline JICA2 & Partnership Program Division & \\
\hline ICLEl1 & Manager, Japan Office & ICLEI-Local Governments for Sustainability \\
\hline ICLEI2 & Program Officer, Japan Office & \\
\hline $\begin{array}{l}\mathrm{C} 1, \mathrm{C}_{2}, \mathrm{C} 3 \\
\mathrm{C} 4, \mathrm{C5}\end{array}$ & - & Kitakyushu citizens \\
\hline NPO1 & Chairman & NPO Satoyama \\
\hline NPO2 & Staff & \\
\hline $\mathrm{Co} 1$ & Recently retired & Kitakyushu company \\
\hline $\mathrm{Co} 2$ & Recently retired & Kitakyushu company \\
\hline $\mathrm{Co3}$ & Eco Town Researcher & Nippon Steel \\
\hline Co4 & Eco Town Researcher & \\
\hline Co5 & - & Kitakyushu company \\
\hline Co6 & Director, chairman & $\begin{array}{l}\text { Kitakyushu Environmental consultancy agency, } \\
\text { Kitakyushu Interdependent Business Consortium } \\
\text { for Sustainable Development (KICS), K-RIP }\end{array}$ \\
\hline LG1 & $\begin{array}{l}\text { Former director of International Environmental } \\
\text { Strategies Division }\end{array}$ & Kitakyushu Local Government \\
\hline LG2 & - & \\
\hline LG3 & $\begin{array}{l}\text { Director of International Project Division, Water } \\
\text { and Sewer Bureau }\end{array}$ & \\
\hline LG4 & $\begin{array}{l}\text { Manager of Kitakyushu Asian Center for Low } \\
\text { Carbon Society International Environmental } \\
\text { Strategies Division }\end{array}$ & \\
\hline LG5 & $\begin{array}{l}\text { Manager of Kitakyushu Asian Center for Low } \\
\text { Carbon Society International Environmental } \\
\text { Strategies Division }\end{array}$ & \\
\hline LG6 & $\begin{array}{l}\text { Recently retired executive of the } \\
\text { Environmental Bureau }\end{array}$ & \\
\hline R1 & Haiphong JCM project leader and researcher & Kitakyushu Asian Center for Low Carbon Society \\
\hline R2 & Researcher & - \\
\hline IGES1 & $\begin{array}{l}\text { Manager of JCM projects in Surabaya Iskandar } \\
\text { and Haiphong, and researcher }\end{array}$ & Institute of Global Environmental Strategies \\
\hline IGES2 & $\begin{array}{l}\text { Manager of water filtration project in Surabaya, } \\
\text { and researcher }\end{array}$ & Institute of Global Environmental Strategies \\
\hline IGES3 & Researcher & Institute of Global Environmental Strategies \\
\hline KITA1 & Member & $\begin{array}{l}\text { Kitakyushu International Techno-cooperative } \\
\text { Association }\end{array}$ \\
\hline HaipLG1 & Official & Haiphong Local Government \\
\hline HaipLG2 & Official & Haiphong Local Government \\
\hline SuraLG1 & Official & Surabaya Local Government \\
\hline SuraNPO1 & Member & Surabayan NPO \\
\hline SuraC1 & Citizen & Surabaya community member \\
\hline
\end{tabular}

pollution meant that there was no effective system, either local or national, to treat or minimise industrial waste. This led to severe environmental and associated health effects, which became a major trigger for change. Kitakyushu suffered the worst air 
pollution in Japan in the 1960s, however, continued public pressure fostered by women's groups led the local government to begin engaging with the companies responsible, introducing emission limits and pushing them to treat their waste from the 1970s (See Table 3). As shown in Table 2, a wide range of initiatives were carried out in the city, many of which can be considered as experiments, as they often are the first in the country. As a result of these initiatives, the city was widely recognized by multiple national and international awards.

Table 2 Experiments and related key triggers, actors, barriers, linkages

\begin{tabular}{|c|c|c|c|c|c|}
\hline Year & Initiatives/experiments & Triggers & Barriers & Actors & Linkages \\
\hline $1970 \sim$ & Pollution control initiative & $\begin{array}{l}\text { Pollution, health } \\
\text { effects }\end{array}$ & $\begin{array}{l}\text { Political, } \\
\text { cultural and } \\
\text { financial }\end{array}$ & Citizens & $\begin{array}{l}\text { Local government- } \\
\text { citizens-companies }\end{array}$ \\
\hline $1990 \sim$ & $\begin{array}{l}\text { Expanding role of } \\
\text { Kitakyushu International } \\
\text { Techno-Cooperative } \\
\text { Association to include } \\
\text { local government and } \\
\text { accept trainees for } \\
\text { environment-focused } \\
\text { courses, knowledge transfer }\end{array}$ & $\begin{array}{l}\text { Global } 500 \text { Award, } \\
\text { economic decline }\end{array}$ & & $\begin{array}{l}\text { Local } \\
\text { government }\end{array}$ & $\begin{array}{l}\text { Companies-local } \\
\text { government-national } \\
\text { agency }\end{array}$ \\
\hline $1996 \sim$ & $\begin{array}{l}\text { Environmental technology } \\
\text { transfer (ODA) } \\
\text {-'96 Dalian (Pollution) } \\
\text { - '99 Phnom Penh (Water } \\
\text { management) } \\
\text { - '04 Surabaya (composting) } \\
\text { - '10 Haiphong (U-BCF) }\end{array}$ & $\begin{array}{l}\text { Global concern, } \\
\text { economic decline }\end{array}$ & Cultural & $\begin{array}{l}\text { Local } \\
\text { government }\end{array}$ & $\begin{array}{l}\text { Local government- } \\
\text { local government, } \\
\text { NPO-NPO }\end{array}$ \\
\hline 1997 & $\begin{array}{l}\text { "Eco Town" (zero-emission } \\
\text { industrial cluster) }\end{array}$ & Economic decline & $\begin{array}{l}\text { Institutional, } \\
\text { competition/ } \\
\text { external } \\
\text { recycling } \\
\text { market }\end{array}$ & $\begin{array}{l}\text { Local } \\
\text { government }\end{array}$ & $\begin{array}{l}\text { Local government- } \\
\text { private sector- } \\
\text { national agencies }\end{array}$ \\
\hline 2003 & $\begin{array}{l}\text { Higashida Area: } \\
\text { "Green village } \\
\text { development" }\end{array}$ & $\begin{array}{l}2001 \text { Japan Expo } \\
\text { on "Coexistence" } \\
\text { held in Higashida } \\
\text { (Kitakyushu) }\end{array}$ & Institutional & $\begin{array}{l}\text { Private } \\
\text { sector/local } \\
\text { government }\end{array}$ & $\begin{array}{l}\text { Private sector-local } \\
\text { government }\end{array}$ \\
\hline 2010 & $\begin{array}{l}\text { Higashida Area: "Smart } \\
\text { Community Project", } \\
\text { community energy } \\
\text { management and } \\
\text { the creation of energy } \\
\text { "prosumers" (producers/ } \\
\text { consumers) }\end{array}$ & & $\begin{array}{l}\text { Pressure from } \\
\text { power } \\
\text { companies, } \\
\text { competition }\end{array}$ & $\begin{array}{l}\text { Private } \\
\text { sector/local } \\
\text { government }\end{array}$ & $\begin{array}{l}\text { Private sector-local } \\
\text { government-citizens }\end{array}$ \\
\hline 2010 & $\begin{array}{l}\text { Establishment of Asian } \\
\text { Center for Low Carbon } \\
\text { Society by the mayor: } \\
\text { institution of environmental } \\
\text { business matchmaking, } \\
\text { promotion joint ventures } \\
\text { with developing Asian cities }\end{array}$ & $\begin{array}{l}\text { Economic decline, } \\
\text { global concern }\end{array}$ & $\begin{array}{l}\text { Cultural, } \\
\text { financial, } \\
\text { political }\end{array}$ & $\begin{array}{l}\text { Local } \\
\text { government/ } \\
\text { private } \\
\text { sector }\end{array}$ & $\begin{array}{l}\text { Local government- } \\
\text { private sector } \\
\text { partnership }\end{array}$ \\
\hline 2010 & $\begin{array}{l}\text { Environmental SMEs } \\
\text { business expansion in- } \\
\text { Haiphong (U-BCF expansion) } \\
\text { - Surabaya (recycling plant) } \\
\text { - Surabaya (industrial cluster) }\end{array}$ & $\begin{array}{l}\text { Economic decline, } \\
\text { global concern }\end{array}$ & $\begin{array}{l}\text { Cultural, } \\
\text { financial, } \\
\text { political }\end{array}$ & $\begin{array}{l}\text { Private } \\
\text { sector }\end{array}$ & Business-business \\
\hline 2011 & FutureCity Initiative & $\begin{array}{l}\text { Ageing } \\
\text { population and } \\
\text { economic decline }\end{array}$ & $\begin{array}{l}\text { Social, } \\
\text { financial }\end{array}$ & $\begin{array}{l}\text { Local } \\
\text { government }\end{array}$ & $\begin{array}{l}\text { Local government- } \\
\text { business-citizens }\end{array}$ \\
\hline
\end{tabular}


Triggers for experimentation

Kitakyushu's current approach to sustainability is the result of a wide range of elements that have influenced its trajectory and directed sustainability experimentation. This section presents the elements, as identified by interview participants, that triggered Kitakyushu's urban sustainability experimentation. All Japanese respondents noted two major triggers: health impacts caused by severe pollution, and economic decline. These were widely identified in relation to two separate time periods-first, the pollution abatement phase from around the 1960s to the 1980s, and second, the phase of economic decline from the 1980s to present.

All respondents identified severe pollution as the starting point of Kitakyushu's approach to sustainability and urban revitalisation. The response, however, was not intended as an ongoing sustainability strategy: "So there wasn't CO2 reduction or 'green' thinking originally, it was because it had impacted people's health and become a social problem that technologies to deal with that were accumulated" (Co1).

Economic decline was identified by respondents as the second major trigger. This was associated with Kitakyushu's long-term strategy of fostering environmental industry and linkages with developing Asia. Many respondents, including the majority of local government respondents, referenced the city's "existence being threatened" or a "sense of crisis" due to economic structural change. Nippon Steel, which was a major employer, suffered a loss in 1986 due to increasing international competition. Co2 directly stated, "Nippon Steel was the trigger". Other industry respondents elaborated on why this triggered the local government to encourage more innovation in the city as the steelworks company had shifted its main base, "and then workers disappeared and technology left [to Tokyo]". Local government officials also agreed, and recall asking, "how can we keep the city going?" (LG3).

This trigger was also noted by LG4, who identified it as a pressure for policy change and also noted that there was an awareness that the environment was Kitakyushu's strength, as it had environmental management resources due to its past efforts at overcoming pollution.

\section{The role of actors in enabling experimentation}

Various actors have played an important role in enabling or supporting Kitakyushu's sustainability experimentation. The role of actors was not static and changed as Kitakyushu's sustainability transition progressed.

\section{Citizens' vision of sustainable urban change}

Participants from local government, businesses and civil society stated that women's groups were the most important agents for change towards pollution abatement. As stated by LG6, who worked as the Chief Executive of the Environmental Bureau, "when understanding how Kitakyushu overcame pollution, it is impossible to ignore the role of the women's [groups]. I think they were the first to do NPO ['not-for-profit' environmental group] activities in Japan". The women's group alerted the wider public to the state of the environment and its health impacts, motivated to protect their children's health. Rather than use legal avenues or public demonstrations, the group's strategy 
was to conduct experiments that demonstrated the impacts of pollution, and to collect data, which was then disseminated through the media.

The women's groups pushed for local government and industry to implement measures that would reduce pollution. Their vision for improved environmental quality culminated in the creation of a film titled "We Want Our Blue Skies Back" that was disseminated not only in Kitakyushu but also throughout Japan. Local government and civil society group respondents described the campaign as a "silent battle" that was unique compared to the other anti-pollution campaigns across Japan. For example, LG5 explained why this connected to further sustainable innovation: "Rather than demanding the companies pay them off for all the harm they had caused, the citizens asked them to invest in green technology to protect them" (LG5).

Kitakyushu has been hailed as the pioneer in establishing voluntary agreements between government and industry (Sugiyama and Imura 1999). The on-the-ground perception, however, seems to be more complex. All the local government officials highlighted the partnership between industry, local government and citizens' groups. However, R2 stated that, "in reality they were not trusting each other [...] but only a beautiful story remains". They stated that in retrospect people noticed the importance of the partnership.

\section{The changing roles of actors and agency}

Though citizens' environmental awareness was framed by respondents as remaining high since the city significantly reduced pollution, respondents from companies and civil society groups described citizens as playing less of an active role in pushing change in the second stage (1980s - today).

As women's groups' efforts became effective, they did not need to push as hard, and their mission was taken up by the local government. Several respondents stated there was a clear shift in the role of actors, whereby the citizens' activity had inspired the local government to take the leading role. For example, Co3 stated that there is no longer a sense of civil society enthusiastically lobbying and engaging with environmental issues, rather "those matters are being entrusted to the local government". Some community members expressed support for the local government's promotion of environmental conservation and educational spaces where citizens could learn about Kitakyushu's history and natural environment, however, they also acknowledged the large role of local government in the city's vision (C5). Also expressed was a concern that citizens are no longer actively involved in designing the city's sustainable future, with the pollution and associated health concerns no longer such an issue (NPO1 and Co3). This concern was not shared by local government officials, as LG2 considered some groups as still active, and LG6 interpreted the process more positively as a "synergy", whereby, with a clear vision for the future from the leaders, citizens can work towards the same goal.

\section{Political leadership}

Political leadership played a significant role in prompting innovative changes in the city's institutional environment that enabled ongoing sustainability experimentation (see Table 3 and Table 2). The majority of respondents (20) mentioned the importance of leadership. Most indicated that the Eco Town experiment and growing 
environmental cooperation linkages with developing Asia would not have happened in such a rapid, frontrunner way, if at all, without Mayor Sueyoshi's (1987-2007) leadership. LG6 who was Executive of the Environmental Bureau stated: "the top person in government is extremely important. The reason why I could do these kinds of challenges [Eco Town and Higashida experiments] was because of Kitakyushu's mayors".

The main reason why Sueyoshi was cited as such an important actor was because of his efforts to build a vision of fostering a new environmental "green growth" industry, and leading corresponding institutional innovation in local government, such as the establishment of the "one-stop service", the Environmental Industries Promotion Office, to attract industries to the Eco Town experiment. Co4 described how Sueyoshi's desire to establish this new sustainable development paradigm outweighed the political risk of importing rubbish for a recycling plant, and Kitakyushu was quick to establish its environmental industry compared to other cities. Co1 also noted that Kitakyushu's success did not hinge on its technological innovation stating that it was really a difference of strategy, i.e. political will.

Co6, who worked for Nippon Steel in the 1960s, and later advised Sueyoshi, recognised Sueyoshi as an important change agent, and commented on the shifting mode of city-to-city cooperation from purely voluntary towards the recognition of the need to incorporate business interests to be sustainable. This shift in thinking led to the establishment of an association, now called 'KICS' [Kitakyushu Interdependent Business Consortium for Sustainable Development] in 1998.

Table 3 Policy overview and environmental recognition

\begin{tabular}{|c|c|c|}
\hline 1967-1987 & \multicolumn{2}{|l|}{ Mayor: Tani Gohei } \\
\hline Goal: Pollution abatement & \multicolumn{2}{|c|}{$\begin{array}{l}\text { Established Environmental Bureau (1971) } \\
\text { 'The City of Kitakyushu Pollution Control } \\
\text { Ordinance' (More stringent than national laws) } \\
\text { Agreements to prevent pollution, began enforcing } \\
\text { measures against major companies, } \\
\text { individualised target-setting }\end{array}$} \\
\hline 1987-2007 & \multicolumn{2}{|l|}{ Mayor: Kouichi Sueyoshi } \\
\hline $\begin{array}{l}\text { Goal: Resource } \\
\text { circulating society, } \\
\text { zero waste emissions, } \\
\text { new environmental industry }\end{array}$ & $\begin{array}{l}\text { "Eco Town Plan" } \\
\text { Development (1990s) of Kitakyushu Eco } \\
\text { Town Plan approved by National } \\
\text { government } 1997 . \\
\text { Creation of an Eco-Industrial Complex ( } 29 \\
\text { plants), Hibiki Recycling Area and Practical } \\
\text { Research Area (15 facilities). Eco Town re- } \\
\text { duces 380,000 t of } \mathrm{CO}_{2} \text { per year (FY2010) } \\
\text { (OECD 2013) } \\
\text { “Grand Design” on World Capital of } \\
\text { Sustainable Development (2004) }\end{array}$ & $\begin{array}{l}1990 \text { United Nations } \\
\text { Environment Programme Global } \\
500 \text { Award } \\
1992 \text { Earth Summit UN Local } \\
\text { Government Honours } \\
1995 \text { Asian Environmental Award } \\
2002 \text { Johannesburg Declaration } \\
\text { recognised the Kitakyushu } \\
\text { Initiative (Knowledge-sharing } \\
\text { network of cities) } \\
\text { 2007-2008 Japan's Top Eco-City } \\
\text { Contest first place }\end{array}$ \\
\hline 2007 - present & \multicolumn{2}{|l|}{ Mayor: Kitahashi Kenji } \\
\hline $\begin{array}{l}\text { Goal: Low Carbon society } \\
50 \% \text { emissions reduction by } \\
2030 \text { on } 2005 \text { levels and } 150 \% \\
\text { Asian region-wide }\end{array}$ & $\begin{array}{l}\text { "Green Frontier Plan" } \\
\text { Established the Asian Center for Low Carbon } \\
\text { Society, which is a grouping of local } \\
\text { government, research institute and public } \\
\text { body, the Kitakyushu International Techno- } \\
\text { Cooperative Association, aimed at expand- } \\
\text { ing environmental business through city-to- } \\
\text { city cooperation. }\end{array}$ & $\begin{array}{l}2008 \text { Approved as an Eco-Model } \\
\text { City (Japan) } \\
2011 \text { Approved as a Future City } \\
\text { (Japan) } \\
2013 \text { "Green Asia" } \\
\text { Comprehensive Special Zone } \\
\text { 20\% of company earnings } \\
\text { involved in relevant projects } \\
\text { deducted from tax. }\end{array}$ \\
\hline
\end{tabular}




\section{Linkages and system dynamics}

Linkages were seen as important for capturing momentum from triggers. Horizontal linkages, particularly between business and local government, were important for overcoming institutional and economic barriers and building support for and enabling new sustainability initiatives. Vertical linkages were important for growing resources towards the city's approach. Figure 1 is a systems causal diagram that shows how the diverse elements, including the triggers and actors mentioned above, interact across horizontal and vertical linkages to form a system that builds momentum and fosters Kitakyushu's approach to urban revitalisation and sustainability. A series of reinforcing loops and a balancing loop are presented in this figure, which was identified based on analysis of the collected data (see Table 4 for detailed description). Momentum for positive change is created and sustained by a succession of self-reinforcing feedback loops - there is a temporal element as link 1 with environmental degradation extent and dissemination of data started the first loop, with the other loops following on. This illustrates the mechanism of sustained frontrunner status through a series of reinforcing feedback loops which shaped the city's identity.

\section{Horizontal linkages}

The interplay of expectations of change between local government and business led to close horizontal linkages, enabling local governance. Kitakyushu began constructing long-term sustainable development goals involving business (LG6). While Nippon Steel had expectations of profitable change for the area, which it owned and hoped to sell, the local government was motivated by the desire to make the Eco Town experiment a success and thus worked closely with the established company: the links between local government and industry were necessary (Co4). As can be seen in Fig. 1, there was feedback related to increasing business and local government activity. The success of Kitakyushu's approach to urban revitalization-moving quickly to establish a positive environment for environmental businesses-created business opportunities and

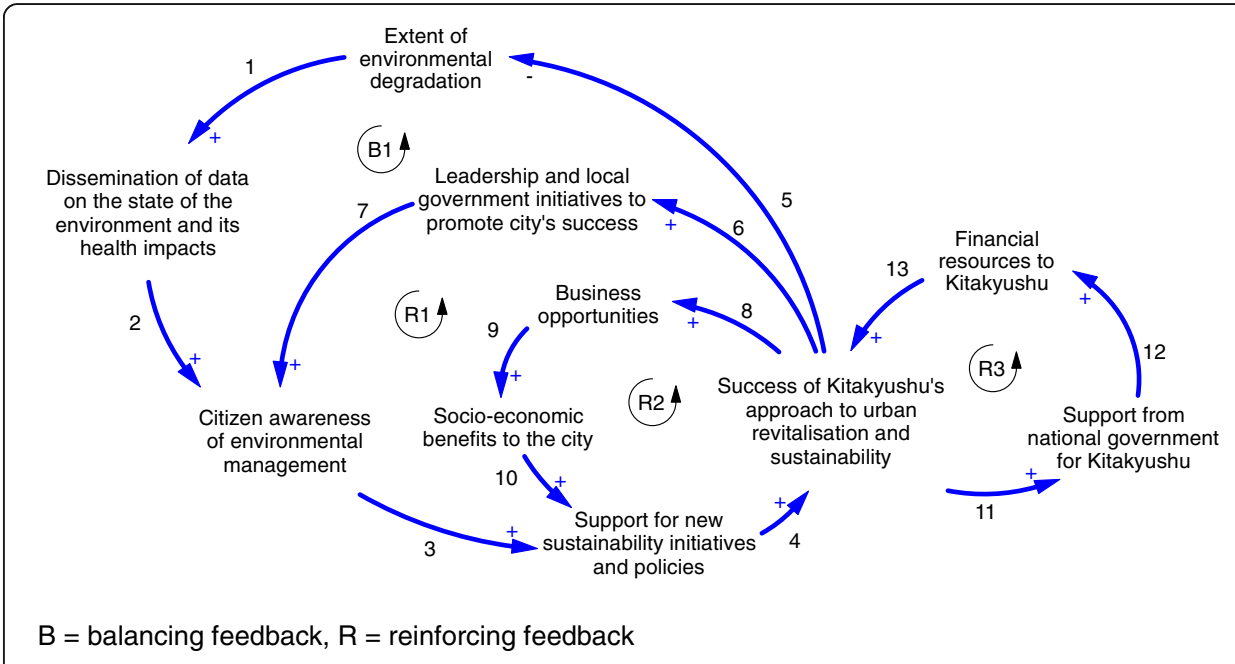

Fig. 1 Systems diagram of Kitakyushu's sustainability experimentation. See Table 4 below for explanation 
Table 4 Explanation of links and loops from internal activities shown in Fig. 1. Urban environmental degradation triggered action whereby the city supported an approach, which in time brought support from the national government

\begin{tabular}{|c|c|c|}
\hline Loop & Links & Description \\
\hline B1 Citizen awareness & $1-2-3-4-5$ & $\begin{array}{l}\text { Kitakyushu's severe environmental degradation } \\
\text { in the 1960s caused women's groups to campaign } \\
\text { and experiment to produce data on the effects of } \\
\text { pollution, as they were concerned for their children's } \\
\text { health. They raised enough awareness to exert pressure } \\
\text { on the local government and to generate support for } \\
\text { new policies that addressed urban sustainability. As the } \\
\text { state of the environment improved fewer people experienced } \\
\text { adverse health impacts, and there was less urgency among } \\
\text { citizens to promote data-collection by groups on how } \\
\text { the environment was being managed. }\end{array}$ \\
\hline R1 Local government leadership & $6-7-3-4$ & $\begin{array}{l}\text { By the 1970s the dominance of loop B1 declined, } \\
\text { as the effect of loop R1 increased. The local government } \\
\text { took advantage of the past efforts of the citizens (B1) } \\
\text { who initiated and drove a campaign focused on urban } \\
\text { sustainability. Local government exercised better political } \\
\text { leadership and supported activities, which maintained } \\
\text { citizen awareness of urban environmental management } \\
\text { strategies and support for new policies. }\end{array}$ \\
\hline R2 Business effects & $8-9-10-4$ & $\begin{array}{l}\text { Success in approaching urban revitalisation and } \\
\text { sustainability increased business opportunities. } \\
\text { For example, the local government made linkages } \\
\text { with local business to create an institutional environment } \\
\text { that would encourage environmental business. } \\
\text { Kitakyushu's Eco Town project saw } 29 \text { environmental } \\
\text { businesses set up an environmental recycling industrial } \\
\text { park, and increase employment and investments. It is } \\
\text { used as an educational and research resource to } \\
\text { continue developing sustainability innovations. It is } \\
\text { now a central part of Kitakyushu's Eco Tourism business. } \\
\text { Business has played a role in supporting continued new } \\
\text { initiatives in the city. }\end{array}$ \\
\hline R3 National level support & $11-12-13$ & $\begin{array}{l}\text { Success in the city's approach generated support from } \\
\text { the national government. For example, the national } \\
\text { government has used Kitakyushu as a show-case, } \\
\text { supporting its efforts, and has continued to provide } \\
\text { financial resources to continue experiments or to establish } \\
\text { new ones, for example, Higashida 'green village', international } \\
\text { cooperation, and new institutions, such as the Centre for } \\
\text { Asian Low-Carbon Society. }\end{array}$ \\
\hline
\end{tabular}

increased the role of local government. In discussing horizontal linkages, LG6 emphasised linkages for coordination of actor roles and sharing a vision between government, businesses and citizens, stating, "businesses and Kitakyushu local government made a new society. To do that, together they first designed the ideal form it should take". Figure 1 demonstrates how government leadership to connect with citizens and maintain environmental awareness to support experimentation fed back into the success of Kitakyushu's approach.

Most respondents-including those from companies, civil society groups and local government-felt that the sharing of a common vision among business, local government and civil society was important for long-term orientation towards sustainability goals and creating strong linkages. For example, Co2 reflected "everyone exactly shared a mission of building and acting on that strategy. It is a very big point that that mission has continued". LG6 also described how experiments presented platforms for promoting transition and linkages: 
If a platform is made that everyone can share, that can continue to be a platform from which to step up. Even if it takes time. For the waste problem, the Eco Town project was a step. And the next step was the Higashida town development. [...] various people, university professors, people who were interested, everyone, gathered at the Higashida Eco Club.

In the case of the Higashida project led by local government and businesses, which included a form of eco-city suburb development, the process went beyond the technical creation of sustainable urban areas and the promotion of economic development. The civil society group Satoyama emphasised how it was aiming to create feelings of connectedness of the inhabitants, and bring companies, workers and residents face-to-face as part of developing a "smart community".

\section{Vertical linkages}

Vertical linkages (enabling forms of multi-level governance) with national agencies have supported sustainability experimentation for change and there is feedback between funding and experimentation. National government funding has been necessary to carry out some of Kitakyushu's larger sustainability experiments, such as the Eco Town, the Higashida community energy management project and also experiments overseas. Having established horizontal linkages through the study group and building a vision for the Hibikinada Area as an Eco Town that would attract business and grow Kitakyushu's local economy, it was found that the area would not be profitable without protection of this new niche market. As shown in Fig. 1, however, Kitakyushu could bolster support from the national government by highlighting its past environmental successes and presenting its strategy. The national government introduced a recycling law, which would secure part of the market for recycling goods. This helped overcome the initial barrier-the absence of a secure market. ICLEI1 stated that it was even easier for Kitakyushu to receive funding after being declared an Eco Model City and a Future City. GOV1 shared a similar view, and described how Kitakyushu was used as a showcase, and the national government had taken high-level visitors from across Asia to visit Kitakyushu's Higashida Smart Community and Eco Town. Loop R3 (Fig. 1) demonstrates how increased financial resources and support have not only bolstered Kitakyushu's success but also inspired the government to continue supporting the city. GOV1 elaborated on the city's relationship with national-level: "When it comes to getting funding, the reason for Kitakyushu's forward-thinking strategy is that it can appeal to so many places. And by appealing to the national [government] the following year [of starting an experiment] it is easy to get budget the next year, for that reason, we are indirectly supporting [Kitakyushu]". As represented in Fig. 1 there is positive feedback between Kitakyushu's approach and support from the national government. GOV1 stated, "there is feedback, 'you did well, so let's support the next [project] a bit more', that kind of support. A good loop is operating where there is continuous progression as support from the national level has formed a successful loop with the actual activities of Kitakyushu" (GOV1).

Though GOV1 was not aware of how such a system began, he was aware of its existence. Vertical linkages have continued to play an important role as Kitakyushu's Smart Community project received national funding, and funding from the national 
government enables the functioning of Kitakyushu's technology transfer engine the "Asian Low Carbon Society Centre" (established 2010). Its aim is to upscale innovative sustainable urban technologies developed by Kitakyushu city businesses into developing Asian cities. Both horizontal and vertical linkages are playing a role in enabling and supporting Kitakyushu's sustainability experimentation.

\section{Barriers to sustainability experimentation}

The most important barriers initially were political will and institutional arrangements. LG6 expressed that, "the established ways of doing things becomes a barrier", but that "having a person at the top who will let us challenge that, gives us confidence to challenge the accepted thinking". Following this, two powerful barriers to facilitating ongoing sustainability experimentation were raised: economic factors, and the lack of the concept of corporate environmental responsibility. Changing the approach of business was a barrier that was overcome through pressure initiated by first citizens and then the local government to innovate and change industrial practices.

Several interviewees acknowledged the paradigm shift in terms of corporate environmental responsibility. Co1 stated that "waste was seen as joint output, a sign of prosperity from creating products. It wasn't that Nippon Steel was bad, it was just that the concept [of spending money on waste treatment] didn't exist in society, so all Japan experienced pollution". The biggest barriers in terms of transforming business approach came from within the company-the sentiment of "why do we have to invest in something that doesn't create profit?", as noted by LG6. Convincing internal stakeholders to shift focus from short-term profit to long-term potential future profit took the most time.

Numerous external pressures in terms of product selection were exerted on companies to innovate their technology and practice to mitigate pollution and treat waste (LG6), while new concepts such as "eco-town" were developed (Co1, LG6). Describing the Eco Town experiment, LG6 stated, “in a business sense, there weren't many people who were happy. It took seven years until it was established, and during that process everyone really did things like spin out. There were many people like that", highlighting the economic difficulties.

\section{Positive inertia and embedded frontrunner identity}

Kitakyushu's approach to urban revitalisation and sustainability was based on the two pillars of fostering environmental industry and internationalising its urban environmental governance. The emergence of a succession of positive feedback loops explains the increasing strength of vertical linkages, resources available to engage in experimentation, and associated self-identity. This creation of the system dynamics described above (Fig. 1), generated a path dependency, what we call here a positive inertia. We define positive inertia as an emergent property at urban system level, where positive approaches are embedded into the city's identity and thus not influenced by short-term political cycles. In Kitakyushu's case, the positive inertia is formed through a succession of a series of positive feedback loops, which over time helped form an embedded identity as a frontrunner. Such embedded identity is in turn supported and reinforced via the citizens' perceived self-identity. 
The increasing resources available to the city also enabled it to widen the scope of its mandate to form environmental cooperation linkages with cities in developing Asia, while economic decline provided motivation to utilise these spaces of flows for environmental joint ventures and SMEs expansion. Barriers such as political will, short-term thinking by industry and uncertainty surrounding system change initially hindered the progress of experimentation, but the positive feedbacks caused by horizontal and vertical linkages reinforced the nature of the city's "frontrunner" dynamic. This meant that even with the change of leadership, Kitakyushu would continue to pursue a frontrunner role.

This approach is embedded in the city's identity and relates to the historical development of systems dynamics depicted in Fig. 1. Kitakyushu's identity as a frontrunner has become embedded and no respondents could envision Kitakyushu pursuing different goals or local government leaders changing the city's commitment to sustainable urban development: "Even if the mayor changes, by this time I don't think it will change [...] we have a path" (LG4). The risk of changing the city's frontrunner nature was considered small by R1 as well, stating "the environmental technology development field is one of the biggest directions of the city. It is a pillar. No one can change the big pillar". One of the reasons raised was that the local government continued to have a strong mandate due to the Grand Design of 2004 that involved a year-long process of consultation to reaffirm the direction for the city towards becoming a 'world capital of sustainable development'. The 2009 Green Frontier Plan established Kitakyushu's carbon reduction goals for within Kitakyushu and in wider Asia, and the Asian Low Carbon Society was established by the mayor to help reach these goals, with funding from national agencies.

\section{Kitakyushu's role in promoting urban sustainability in the region}

Kitakyushu's internal success led to increased international recognition, cultivating its strategy to export their technologies and expertise to cities in developing Asia. This led to city-to-city collaboration with several cities in Asia. The Kitakyushu Initiative Network, which was established at the UN ESCAP Ministerial Conference on Environment and Development (2000), was helpful for the city to identify potential partners. Two examples include Surabaya and Haiphong. Kitakyushu city began experimenting with composting methods to assist in improving Surabaya's waste management issues in 2004. Experimentation with water management in Haiphong began in 2010. There have been multiple environmental initiatives since, and Surabaya is now a Green Sister City (2012 ) and Haiphong is a Sister City (2014 ). Surabaya sought to upgrade their cityto-city relationship from a Joint Statement on Strategic Environmental Partnership to Sister Cities because of the urgency of current environmental management issues, such as waste management, water treatment, sanitation and reduction of greenhouse gases (SuraLG1). Both relationships have been built up towards environmental business joint ventures from ODA-funded sustainability experimentation in each city, aimed at assisting these cities with environmental issues.

As described by Co1, there were two modalities of Kitakyushu's engagement with other cities on sustainability: one is providing technology or knowhow owned by the Kitakyushu city government on infrastructure and water supply, and the other is the 
local government coordinating for the private companies of Kitakyushu that can provide technology.

Successful cooperation led to the good relationships between Kitakyushu and Surabaya today. For example, "it is a good partner city because of the [Takakura] composting project. There was no successful composting before Takakura" (R1). A member of a Surabayan NPO felt that Kitakyushu assisted in alleviating Surabaya's waste problem, stating "they introduced the Takakura Basket that effectively reduces waste from households. The community very much welcomed that technology. We hope more technology can be applied in Surabaya" (SuraNPO1). This project was upscaled to other cities in developing Asia, receiving strong promotion by the city and JICA.

In the case of Haiphong, the success of experimentation with Kitakyushu local government's U-BCF water filtration technology contributed to the cities' decision to become sister cities and continue collaboration. The technology was purchased by Haiphong and other cities in Vietnam have since applied to experiment with it. Kitakyushu also accepted trainees from developing countries for environmental management, more so than other cities: R2 commented, "other cities aren't so interested, and can't see so well how it connects". In Kitakyushu's case, collaboration with other cities has been a key part of its strategy to revitalise its economy.

The two major motivations of Kitakyushu to engage with other cities were described by respondents as: contributing to Asia's sustainability transition and business expansion. Both were generated through city-city collaboration. Business opportunities increased following the changing nature of collaboration: "there has been a transition. [...] Now, though they are supporting business expansion, they still say international cooperation" (R1). Local government officials described the increasing involvement of business as necessary for carrying out sustainability experiments that continue beyond the experimentation stage. Figure 2 depicts the local government's shift in policy regarding international cooperation.

\section{Perspectives from Surabaya and Haiphong}

Surabaya's respondents viewed Kitakyushu as playing an important role in facilitating environmental improvement and linked the city's collaboration to behavioural change, new regulations and technology transfer that had occurred in the city.

Cooperation with Kitakyushu was credited for the introduction of new regulations, such as one to institutionalize community-based waste management. SuraLG1 agreed that Kitakyushu had made a positive impact: "For example, the compost making technique, and encouraging people who live along the river to keep the environment,

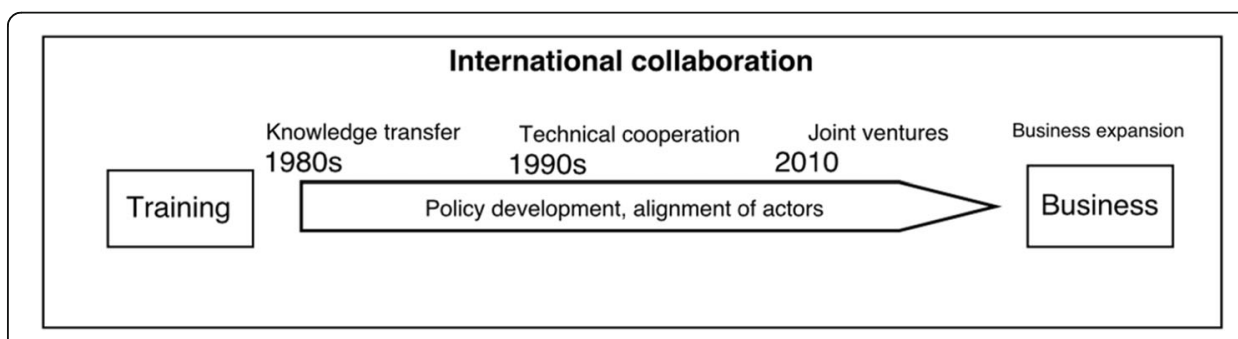

Fig. 2 Policy shift towards business expansion 
especially the river along their village, clean". This view was echoed by a community member, stating "the main benefits for the community include raising awareness, learning and aid related to the environment" (SuraC1). SuraLG1 felt the role was "very important" and described the partnered projects, Super Depo and Wonorejo, waste management initiatives, as successes.

Kitakyushu's role in Haiphong was seen as enabling faster transition towards sustainability by improving local government environmental management and building longterm visions of change. Similar to Surabaya's respondents, those in Haiphong also placed an emphasis on technology transfer, yet they spoke more about the benefits of business-driven projects. This was linked to advancement of JCM projects. Regarding what kind of role Kitakyushu local government had played, HaipLG2 stated: "Kitakyushu has made practical contributions to encourage changes towards sustainability in Haiphong, including: orientation for key roles and responsibilities of the city's administrative units and vision".

Similar to HaipLG2, HaipLG1 also viewed Kitakyushu as playing a role in improving local government capacity. When asked whether the experiments and learning from them will play an important part in Haiphong's transition towards green growth, HaipLG1 stated that "even in the first step of conducting studies, not implementation, there was noticeable improvement". Cooperating with Kitakyushu on these projects necessitated various local government departments' sharing of information and improvement of information access, as well as stakeholder cooperation. Kitakyushu's involvement was considered to have directly increased the prominence of sustainability on the city's political agenda and caused the leader of the city to focus more on sustainable planning (HaipLG1).

\section{Forming a system of collaboration and proactive influencing}

Figure 3 and Table 5 present a system level analysis, showing how Kitakyushu is promoting urban sustainability in the region and captures various interrelated factors that show why there is dynamic two-way motivation for engagement. Figure 3 shows the multiple reinforcing loops influencing the success of Kitakyushu's approach, similar to

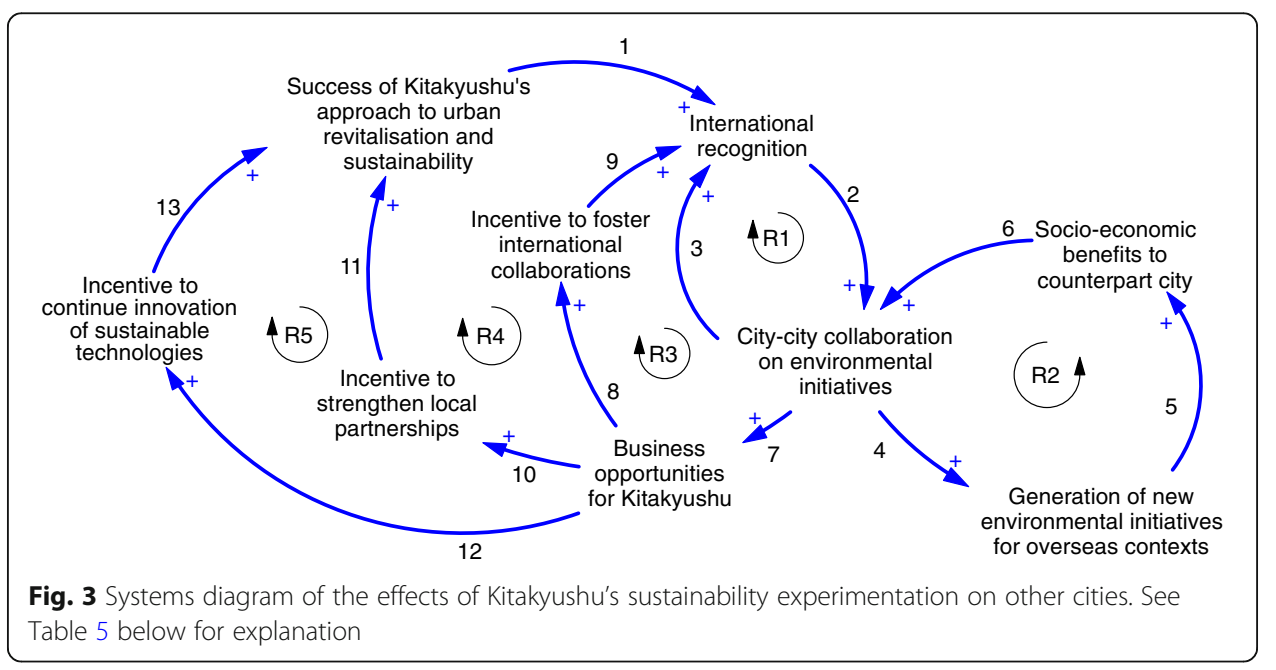


Table 5 Explanation of feedback loops from city-city collaboration shown in Fig. 3. Internal success attracted the attention of other cities in the region

\begin{tabular}{|c|c|c|}
\hline Loop & Links & Description \\
\hline R1 Engagement & $2-3$ & $\begin{array}{l}\text { Increased international recognition of Kitakyushu as an } \\
\text { environmental frontrunner has seen requests from other } \\
\text { cities and from the national level to be involved in } \\
\text { collaborative sustainability initiatives. Kitakyushu initially } \\
\text { leveraged its increased reputation to establish linkages } \\
\text { with other cities for collaboration. These proactive } \\
\text { networking activities, such as the Kitakyushu Initiative, } \\
\text { have in turn increased international recognition. }\end{array}$ \\
\hline R2 Spread of innovation & $4-5-6$ & $\begin{array}{l}\text { City-to-city collaboration has generated new } \\
\text { environmental initiatives in new contexts. For } \\
\text { example, the composting initiative in Surabaya led to } \\
\text { a new locally appropriate method of composting. In } \\
\text { Haiphong, experiments in U-BCF filtration technology } \\
\text { led to Haiphong purchasing the Kitakyushu technology. } \\
\text { Further experiments with it are underway in other parts } \\
\text { of Vietnam. This collaboration has brought socio-economic } \\
\text { benefits to these cities, such as reduction of waste and } \\
\text { lower cost, lower-energy water-filtration methods } \\
\text { respectively. As collaboration initiatives increased, } \\
\text { networks were strengthened. }\end{array}$ \\
\hline
\end{tabular}

R3 New markets $\quad 2-7-8-9$

City-to-city collaboration initiatives have increased business opportunities for Kitakyushu businesses. For example, both Haiphong and Surabaya local governments have introduced ideal business counterparts to Kitakyushu businesses based on a two-way dynamic motivation (capacity building and economic). It is especially difficult for SMEs to take environmental products or services abroad. Thus, Kitakyushu's strategy, of tapping into new markets in developing Asia for environmental solutions, benefits SMEs. The number of local government officials dedicated to environmental industry development and international cooperation has increased. For example, the establishment in 2010 of the local government's Asian Centre for Low-Carbon Society, as well as the Kitakyushu Overseas Water Business Association. The national government is providing a 50\% subsidy to overseas low-carbon ventures under the Joint Crediting Mechanism, which Kitakyushu is leveraging to foster international collaborations. Its activity has garnered it even more international recognition.

The success of Kitakyushu's approach has increased international recognition through various international awards and especially following the OECD 2011 selection of Kitakyushu as a model city of Green Growth. Visits by world leaders have also raised the city's profile. China's president Xi Jinping described Kitakyushu as a "successful model of environmental protection" (2009). Thus increasing collaboration and business opportunities have provided an incentive for both local government and businesses to work together. While the domestic market is shrinking, there is high demand for environmental solutions, such as pollution control, recycling business, etc. in developing Asian markets. Kitakyushu local government strategy is to reinvigorate the local economy through helping its environmental SMEs to expand overseas and be more involved in collaborative experiments. The incentive to build up existing linkages between local government and business, and to work together, is contributing to the success of Kitakyushu's approach by aligning mutual interests to a common goal. 
Table 5 Explanation of feedback loops from city-city collaboration shown in Fig. 3. Internal success attracted the attention of other cities in the region (Continued)

\begin{tabular}{ll}
\hline Loop Links & Description \\
\hline & For example, Kitakyushu Science Research Park and Water Plaza \\
& have engaged in commercial R\&D experimentation with \\
& technologies aimed at meeting the needs of other cities. The \\
& Kitakyushu Urban Centre of the Institute for Global Environmental \\
& Strategies has also contributed research on policy strategies that \\
& could be applied elsewhere. These experimental hubs contribute \\
& to Kitakyushu's approach by acting as both centres of research \\
& and innovation that can act as showrooms for other cities to visit. \\
\end{tabular}

the previous systems diagram. As reflected in the diagram, the number of city-city collaboration initiatives is increasing, and this is an emerging property of the system that has developed and become embedded. Collaboration generated new initiatives, and Fig. 3 demonstrates how the generation of further initiatives was dependent on and evaluated in terms of socio-economic benefits to the partner city rather than hard technology transfer. The causal loop diagram shows how collaboration contributed to other cities' sustainability and business opportunities, the two main motivations outlined by Kitakyushu stakeholders. Multiple reinforcing loops show how international engagement, spread of innovation, new markets, local partnerships and R\&D have all increased and are relevant to Kitakyushu's approach.

The system represented in Fig. 3 is complex rather than mechanical, and local government officials emphasised emergent properties. For example, they highlighted that now-as shown in Fig. 3-there are "many requests urging us to engage in cooperation" (LG5). This shows the momentum and feedback of increasing linkages resulting from the city's proactive influencing. Visits and praise by world leaders such as the Chinese President Xi Jinping, and the publication of the OECD Green Growth report, which listed Kitakyushu as the only urban Asian model of green growth, have raised the city's profile. Indeed, most interviewees viewed elements of Kitakyushu's experience, such as strategy, long-term planning and linkages across levels of government, cities and businesses as being replicable.

\section{Discussion}

The discussion below focuses on the importance of a succession of different reinforcing loops that help generate a positive inertia. The dynamics discussed characterise the nature and making of a frontrunner city, where embeddedness makes it difficult to sway from a sustainable trajectory, and proactive influencing by experimentation in new contexts can contribute to sustainability transition.

\section{Creating positive inertia}

The making of Kitakyushu as a frontrunner city involved a combination of various triggers, actors and linkages, and overcoming various barriers. Severe pollution and economic decline were the two main triggers for Kitakyushu to embark and continue its sustainability experiments, which in turn created windows of opportunity for urban actors-citizens and local government-to promote alternative visions for the city. A clear shift in primary actors can be observed, from citizens to local government. The increased involvement of local government came as a response to the economic decline 
as local government needed to incentivise involvement in sustainability transition for businesses. This indicates that a large level of agency from both civil society and local government is required for creating change within cities at different stages. In Kitakyushu's case, as transition towards sustainability progressed and the citizens' efforts became more effective in motivating the local government, the strength they initially brought was taken up by the local government. This momentum was sustained as local government constructed a vision and policies that linked economic growth with fostering new environmental industries. This shift in agency can be understood as a shift in the dominant feedback (Fig. 1). Government leadership was strengthened based on the success of its approach to urban revitalisation and sustainability. The most important initial barrier was establishing the political will and institutional arrangements, and subsequently economic factors and markets drivers - this supports existing literature (Bai et al. 2010).

Political leadership built the confidence of multiple actors, including other local government agencies and created business opportunities. This was important for enabling businesses to play a key role in experimentation and contribute to visions for the future. This suggests that co-evolution of business and government is important to sustainable urban development, and reflects research on the governance role that experimentation can play by creating a new political space (Bulkeley and Castan Broto 2013). The interplay of local government and industry's expectations of change led to the creation of horizontal linkages and coordination of their resources to promote change. Vertical linkages with national agencies have enabled ongoing sustainability experimentation and there is evidence for feedback between national support and the success of Kitakyushu's approach. Transforming the approach of businesses to invest in long-term sustainability and experimentation was hindered by a focus on short-term profits. Local government incentives, such as the Eco Town subsidies and the local government's vision of expanding environmental business in developing Asia, were important for involving business. Internal regimes of local government acted as another barrier to further experimentation. This was overcome by strong political leadership from the city's mayors who encouraged experimentation and gave local government officials the confidence to challenge conventional forms of governance, setting new institutional arrangements.

Four distinct co-evolutionary feedback loops were identified. First was citizens acting as a catalyst, second was local government leadership, third was business related and the fourth was vertical with resources from national government. The systems analysis also indicated that urban sustainability transitions become self-reinforcing when a) triggers present an opportunity for different actors to build momentum towards new sustainability policies and experimentation; b) horizontal linkages with business are formed based on working towards shared visions of change and increasing business opportunities; and c) vertical linkages are established that contribute resources and political support. Although there have been discussions in the past about the causal architecture of failure (see Homer-Dixon et al. 2015), this paper has investigated the emergence of positive inertia.

The findings support and extend the system innovation and transition literature in the following ways. Firstly, the study echoes the view that the successes of sustainability transition are the result of more than simple technological and economic motivations, 
as in Sartorius (2006), but it also shows that system dynamics can in turn promote further technological innovation and economic growth. Secondly, the role of local government leadership, particularly the Mayor Sueyoshi, supports to an extent the view that transitions can be steered, and urban governance challenges overcome (Sengers et al. 2016; Kemp and Loorbach 2003). The system described by the interviewees also indicates characteristics of a complex system, e.g. emergent properties in the outcome. Finally, while the role of agency in transformation is well recognized (Smith et al. 2005), this study shows how the city acts as a system interacting with external elements, in which no single actor can perpetuate the process, but through the succession of actors at different phases of sustainability transition.

As discussed above, 'positive inertia' differs from existing conceptions of 'momentum' (Hughes 1969), which describes how large technical systems build up forces to create change. 'Positive inertia' describes the difficulty of swaying from a sustainable trajectory-referring to the reluctance or resistance to change-in this case the pathdependency of the self-reinforcing drive towards more sustainable futures. From a systems perspective, a positive inertia is a desirable emergent property, and momentum may or may not result in a positive inertia. This distinction is important, as one of the key challenges in urban sustainability is the lack of continuity due to the short political cycle. A change of mayor may, for example, completely change the momentum for sustainable practices, but would be hard to change when positive inertia is in place.

The practical implications of the study relate to building upon initial momentum to create a positive reinforcing cycle that increases success in urban revitalisation and sustainability - and contributes to creating positive inertia. In any city, there are always small triggers that can be leveraged, and this case highlighted the importance of capturing and building on momentum from economic and environmental triggers for sustainability transition. In Kitakyushu's case, civil society started the process that was continued by businesses, and local and national government. The feedback between Kitakyushu's activities and national support was necessary for the city to engage in ongoing sustainability experimentation. Without national support, the necessary financial, political and regulatory resources would not have been available. This indicates that cities, by their nature, require national support for success to be sustained.

\section{Proactive influencing}

Kitakyushu's internal success in building horizontal and vertical linkages was extended through a proactive role in international cooperation. The two causal loop diagrams presented in Figs. 1 and 3 shows how urban experimentation can generate momentum towards sustainability both within and outside of the city. The nature of the cooperation shifted from voluntary assistance to exploring business opportunities, with a twoway dynamic motivation to engage in sustainability experimentation. For Kitakyushu, the business opportunities could be increased concomitantly with a wider range of environmental solutions for partner cities. Compared to international multi-city forums, focused city-to-city relationships produced more direct benefits, such as business opportunities and learning, for both sides. For the two partner cities, the various socioeconomic and environmental benefits and increased business opportunities, lead to an increased motivation towards further collaboration. Both Haiphong and Surabaya's 
respondents saw Kitakyushu as supporting the cities to move faster towards more sustainable trajectories. This was reflected in the positive feedback between the generation of new environmental initiatives and city-city collaboration. The different experiences of collaboration with Kitakyushu appear to relate to the differing environmental issues facing those cities today, such as waste management and green growth. The main role Kitakyushu appears to be playing is enabling new environmental initiatives in other cities, which contribute to new business models, government capacity and financial resources.

In system innovation and transition literature, successful experiments are considered as a starting point of diffusion and transition. Experiments in one place often draw on experiments elsewhere, either directly or indirectly (Berkhout et al. 2010), and upscaling and eventual transition often realized by multiplication, i.e. other cities learning from the frontrunner (Bai et al. 2010). These can be considered as a passive influencing, as the action needs to be the initiative of a party that is external to the frontrunner. Our analysis reveals another mode of diffusion and upscaling, i.e. via proactive influencing, where the frontrunner actively reaches out to other cities and influences their practices. Utilising their own past experience and resources, frontrunners can help provide direction to partner cities to accelerate their moves towards sustainability, as well as tap into new markets for environmental solutions.

The Kitakyushu case study shows the importance of the involvement of multiple actors, including different levels of government and private sectors, as also recognized by De Boer (2009), and is an example of the internationalisation of urban environmental governance through city-to-city cooperation (Broto and Bulkeley 2013). A unique finding from the case study is that it showed how by incorporating an international aspect into its operations at home a city can create benefits and reinforcing feedbacks for itself and partner cities. Further, there are broader spillovers as practices such as Takakura composting and technologies such as U-BCF have since been upscaled to other parts of Indonesia and Vietnam.

\section{Applicability}

The majority opinion of the interviewees was that many elements of the case of Kitakyushu were replicable to other cities. While some factors are inherent to the city, such as being an industrial port city, others such as strategy regarding partnerships, vision crafting, creating permanent spaces for experimentation and education, and lobbying the national government may be transposed to any city worldwide. The key lies in first creating momentum, then capturing and sustaining it through a succession of lead actors and linkages that create positive feedback, i.e. committed citizens, visionary leadership, and industries that are pressured by the society and later seek economic opportunities. External recognition and encouragement at national and international levels can help in embedding the frontrunner identity into the city, creating a positive inertia, reinforced via the citizens' perceived self-identity. The inertia here is not about a single initiative, but referring to an emergent property of a city as a system, whereby positive approaches are embedded into the city's identity. Such system level dynamics and changes can happen in different contexts. 
Nonetheless, contextualisation of experiments and innovation is important when attempted in different cities. Depending on the context, there may be different interplays of elements and the size of the role of key actors, as different cities and countries vary in terms of governance, and business cultures.

\section{Conclusion}

This paper examined how positive momentum has been initiated, built, and sustained towards changing the status quo of practice through a succession of actors, and what the role is of frontrunner cities in sustainability transition beyond their boundary. Three cities were chosen as case study sites-Kitakyushu in Japan as a frontrunner city, and Surabaya in Indonesia and Haiphong in Vietnam as two cities influenced by the frontrunner city. Systems analysis of the triggers, actors, linkages and barriers reveals a complex interplay, and a series of reinforcing dynamics, that enabled Kitakyushu's approach to urban revitalisation and sustainability within and beyond the city. We found that creating the mechanism of sustained frontrunner status through a series of reinforcing feedback loops embedded the frontrunner identity and created positive inertia, which was essential for ongoing experimentation and transition towards sustainability. This emergent property related to a core identity rather than a core set of technology, which past studies of momentum have focused on. Moreover, a city with frontrunner identity and positive inertia in sustainability practice can have numerous flow-on benefits for other cities when it involves proactive influencing supported by its established frontrunner identity. Such proactive influencing, supported by multiple two-way benefits, is a new mainstreaming and upscaling mechanism for urban sustainability experiments towards broader systems innovation and sustainability transition.

Abbreviations

ICLEl: International Council for Local Environmental Initiatives (now officially: ICLEI - Local Governments for Sustainability); IGES: Institute of Global Environmental Strategies; JCM: Joint Crediting Mechanism; JICA: Japan International Cooperation Agency; NPO: Non-profit organisation; ODA: Official development assistance; OECD: Organisation for Economic Co-operation and Development; SMEs: Small and medium-sized enterprises

Acknowledgements

We thank the interviewees in Kitakyushu, Haiphong and Surabaya for sharing their views and insights; Katrina Proust and Jamie Pittock for their helpful advice; and the two anonymous reviewers for their insightful comments.

Authors' contributions

SI conceived of the study, performed the analysis and drafted the manuscript. XB participated in the study's design, supervised the study, and contributed to the writing and revision. All authors read and approved the final manuscript.

\section{Funding}

The fieldwork was supported by the Honour's thesis funding, Fenner School of Environment and Society Director's scholarship, and College of Asia-Pacific Travel Grant at the Australian National University.

Availability of data and materials

Data sharing not applicable to this article as no datasets were generated or analysed during the current study.

Ethics approval and consent to participate

Information collection, storage and presentation are approved by the ANU Human Research Ethics Committee (protocol number: 2015/173).

Consent for publication

Not applicable.

Competing interests

The authors declare that they have no competing interests. 
Received: 21 January 2019 Accepted: 24 September 2019

Published online: 18 November 2019

\section{References}

Acuto M. Give cities a seat at the top table. Nature. 2016;537(7622):611-3.

Affolderbach J, Schulz C. Mobile transitions: exploring synergies for urban sustainability research. Urban Stud. 2016;53(9): 1942-57.

Bai X. The process and mechanism of urban environmental change: an evolutionary view. Int J Environ Pollut. 2003;19(5): $528-41$.

Bai X, Dawson R, Ürge-Vorsatz D, Delgado G, Salisu Barau A, Dhakal S, et al. Six research priorities for cities and climate change. Nature. 2018;555(7694):23-5.

Bai X, Imura H. A comparative study of urban environment in East Asia: stage model of urban environmental evolution. Int Rev Environ Strateg. 2000;1(1):135-58.

Bai X, Roberts B, Chen J. Urban sustainability experiments in Asia: patterns and pathways. Environ Sci Policy. 2010;13(4):31225.

Bai X, Surveyer A, Elmqvist T, Gatzweiler FW, Guneralpe B, Parnell S, et al. Defining and advancing systems approach for sustainable cities. Curr Opin Environ Sustain. 2016;23:69-78.

Bai X, Wieczorek AJ, Kaneko S, Lisson S, Contreras A. Enabling sustainability transitions in Asia: the importance of vertical and horizontal linkages. Technol Forecast Soc Chang. 2009;76(2):255-66.

Batty M. Cities as complex systems: scaling, interactions, networks, dynamics and urban morphologies. Science. 2008; 319(5864):769-71.

Bergek A, Jacobsson S, Carlsson B, Lindmark S, Rickne A. Analyzing the functional dynamics of technological innovation systems: a scheme of analysis. Res Policy. 2008;37(3):407-29.

Berkhout F. Technological regimes, path dependency and the environment. Glob Environ Chang. 2002;12(1):1-4.

Berkhout F, Verbong G, Wieczorek AJ, Raven R, Lebel L, Bai X. Sustainability experiments in Asia: innovations shaping alternative development pathways? Environ Sci Policy. 2010;13(4):261-71.

Broto VC, Bulkeley H. A survey of urban climate change experiments in 100 cities. Glob Environ Chang. 2013:23(1):92-102.

BRT+ Centre of Excellence and EMBARQ. Global BRTData. Version 3.46; 2019. http://www.brtdata.org. Accessed 16 Apr 2019

Bulkeley H, Castan Broto V. Government by experiment? Global cities and the governing of climate change. In: Transactions of the Institute of British Geographers; 2013. p. 38.

Campbell T. Learning cities: knowledge, capacity and competitiveness. Habitat Int. 2009;33(2):195-201.

City of Kitakyushu. Kitakyushu kankyou moderu toshi koudou keikaku; 2009. http://www.city.kitakyushu.lg.jp/files/000166893. pdf. Accessed 10 May 2015

Coenen L, Benneworth P, Truffer B. Toward a spatial perspective on sustainability transitions. Res Policy. 2012:41(6):968-79.

de Boer Y. Sustainable development in times of crises: opposition or opportunity; 2009. https://unfccc.int/files/na/application/ pdf/bonn_symposium.pdf Accessed 10 Sept 2015

Evans J, Karvonen A, Raven, R. The experimental city: New modes and prospects of urban transformation. In Evans J, Karvonen A, Raven, R (Eds.), The experimental city (1-12). London: Routledge; 2016.

Frantzeskaki N, van Steenbergen F, Stedman RC. Sustain Sci. 2018;13:1045.

Frantzeskaki N, Wittmayer J, Loorbach D. The role of partnerships in 'realising' urban sustainability in Rotterdam's city ports area, the Netherlands. J Clean Prod. 2014;65:406-17.

Geels, FW. From sectoral systems of innovation to socio-technical systems. Research Policy. 2004;33(6-7):897-920.

Geels FW. Processes and patterns in transitions and system innovations: refining the co-evolutionary multi-level perspective. Technol Forecast Soc Chang. 2005;72(6):681-96.

Geels FW. Multi-level perspective on system innovation: relevance for industrial transformation. In: Olsthoorn X, Wieczorek A, editors. Understanding industrial transformation. Environment \& Policy, vol. 44. Dordrecht: Springer; 2006. p. 163-86.

Geels FW. The multi-level perspective on sustainability transitions: responses to seven criticisms. Environ Innov Soc Trans. 2011;1(1):24-40.

Geels FW, Schot J. Typology of sociotechnical transition pathways. Res Policy. 2007;36(3):399-417.

Gerlak AK, Heikkila T, Smolinski SL, Huitema D, Armitage D. Learning our way out of environmental policy problems: a review of the scholarship. Pol Sci. 2018;51(3):335-71.

Homer-Dixon T, Walker B, Biggs R, Crépin A, Folke C, Lambin EF, et al. Synchronous failure: the emerging causal architecture of global crisis. Ecol Soc. 2015;20(3):6

Hughes T. Technological momentum in history: hydrogeneration in Germany 1898-1933. Past Present. 1969;44(1):106-32

Jacobsson S, Lauber $\mathrm{V}$. The politics and policy of energy system transformation-explaining the German diffusion of renewable energy technology. Energy Policy. 2006;34(3):256-76.

Kemp R, Loorbach D. Governance for sustainability through transition management. Montreal: Open Meeting of Human Dimensions of Global Environmental Change Research Community; 2003.

Kemp R, Rotmans J. The management of the co-evolution of technical, environmental and social systems. In: Weber M, Hemmelskamp J, editors. Towards environmental innovation systems. Berlin: Springer; 2005. p. 33-55.

Laakso S, Berg A, Annala M. Dynamics of experimental governance: a metastudy of functions and uses of climate governance experiments. J Clean Prod. 2017;169:8-16.

Lange P, Driessen PP, Sauer A, Bornemann B, Burger P. Governing towards sustainability-conceptualizing modes of governance. J Environ Policy Plan. 2013;15(3):403-25.

Lee T, Jung HY. Mapping city-to-city networks for climate change action: geographic bases, link modalities, functions, and activity. J Clean Prod. 2018;182:96-104.

Loorbach D, Rotmans J. Managing transitions for sustainable development. In: Olsthoorn X, Wieczorek A, editors. Understanding industrial transformation. Environment \& Policy, vol 44. Dordrecht: Springer; 2006.

Ma Y, Rong K, Mangalagiu D, Thornton TF, Zhu D. Co-evolution between urban sustainability and business ecosystem innovation: evidence from the sharing mobility sector in Shanghai. J Clean Prod. 2018;188:942-53. 
Mack N, Woodsong C, MacQueen KM, Guest G, Namey E. Qualitative research methods: a data collectors field guide. Research Triangle Park: Family Health International; 2005.

Malerba F. Sectoral systems of innovation and production. Res Policy. 2002;31(2):247-64.

Markard J, Raven R, Truffer B. Sustainability transitions: an emerging field of research and its prospects. Res Policy. 2012;41(6): 955-67.

McCormick K, Kiss B. Learning through renovations for urban sustainability: the case of the Malmö innovation platform. Curr Opin Environ Sustain. 2015;16:44-50.

Meadows DH. Thinking in systems: a primer. White River Junction: Chelsea Green Publishing; 2008.

Nagendra H, Bai X, Brondizio E, Lwasa S. The urban south and the predicament of global sustainability. Nature Sustain. 2018; 1:341-9.

Nevens F, Frantzeskaki N, Gorissen L, Loorbach D. Urban transition labs: co-creating transformative action for sustainable cities. J Clean Prod. 2013;50:111-22.

OECD. Green growth in Kitakyushu Japan: OECD Publishing; 2013, Paris.

Peng Y, Bai X. Experimenting towards a low-carbon city: policy evolution and nested structure of innovation. J Clean Prod. 2018;174:201-12.

Peng Y, Wei Y, Bai X. Scaling urban sustainability experiments: contextualization as an innovation. J Clean Prod. 2019;227:30212.

Quitzau M-B, Jensen JS, Elle M, Hoffmann B. Sustainable urban regime adjustments. J Clean Prod. 2013;50:140-7.

Raven R. Niche accumulation and hybridisation strategies in transition processes towards a sustainable energy system: an assessment of differences and pitfalls. Energy Policy. 2007;35(4):2390-400.

Rotmans J, Kemp R, Van Asselt M. More evolution than revolution: transition management in public policy. Foresight. 2001; 3(1):15-31.

Ruggiero S, Martiskainen M, Onkila T. Understanding the scaling-up of community energy niches through strategic niche management theory: insights from Finland. J Clean Prod. 2018;170:581-90.

Sartorius C. Second-order sustainability — conditions for the development of sustainable innovations in a dynamic environment. Ecol Econ. 2006;58(2):268-86.

Schot J, Geels FW. Strategic niche management and sustainable innovation journeys: theory, findings, research agenda, and policy. Tech Anal Strat Manag. 2008;20(5):537-54.

Schot J, Steinmueller WE. Three frames for innovation policy: R\&D, systems of innovation and transformative change. Res Policy. 2018:47(9):1554-67.

Sengers F, Berkhout F, Wieczorek A, Raven R. Experimenting in the city. Unpacking notions of experimentation for sustainability. In: Evans J, Karvonen A, Raven R, editors. The experimental city. London: Routledge; 2016.

Seyfang G, Smith A. Grassroots innovations for sustainable development: towards a new research and policy agenda. Environ Politics. 2007;16(4):584-603.

Smith A, Stirling A, Berkhout F. The governance of sustainable socio-technical transitions. Res Policy. 2005;34(10):1491-510,

Sugiyama R, Imura H. Voluntary approaches in Japan: proven record of pollution control agreements and new industrial initiatives for the protection of the global environment. Corp Soc-Respons Environ Manage. 1999;6(3):128.

Truffer B, Murphy JT, Raven R. The geography of sustainability transitions: contours of an emerging theme. Environ Innov Soc Trans. 2015;17:63-72.

United Nations, Department of Econmic and Sovial Affairs, Population Division. 2018 revision of world urbanization prospects; 2018.

van der Heijden J. City and subnational governance: high ambitions, innovative instruments and polycentric collaborations? In: Jordan A, Huitema D, Van Asselt H, Forster J, editors. Governing climate change: Polycentricity in action? Cambridge University Press, Cambridge; 2018.

Voytenko Y, McCormick K, Evans J, Schwila G. Urban living labs for sustainability and low carbon cities in Europe: towards a research agenda. J Clean Prod. 2016;123:45-54.

Wolfram M. Assessing transformative capacity for sustainable urban regeneration: a comparative study of three south Korean cities. Ambio. 2019:48(5):478-93.

Wolfram M, Van der Heijden J, Juhola S, Patterson J. Learning in urban climate governance: concepts, key issues and challenges. J Environ Policy Plan. 2019;21(1):1-15.

\section{Publisher's Note}

Springer Nature remains neutral with regard to jurisdictional claims in published maps and institutional affiliations.

Ready to submit your research? Choose BMC and benefit from:
- fast, convenient online submission
- thorough peer review by experienced researchers in your field
- rapid publication on acceptance
- support for research data, including large and complex data types
- gold Open Access which fosters wider collaboration and increased citations
- maximum visibility for your research: over 100M website views per year
At BMC, research is always in progress.
Learn more biomedcentral.com/submissions

